\title{
The impact of dementia in the prison setting: A systematic review
}

\section{Reference:}

Brooke, J., Diaz-Gil, A, Jackson, D. (2018). The impact of dementia in the prison setting: A systematic review. Dementia: the international journal of social research and practice DOI:10.1177/1471301218801715

\section{Abstract}

Older prisoners are the fastest growing group in the prison population, with an accelerated aging process they are at a high risk of developing dementia. However, no systematic review has explored the impact of dementia in the prison setting. The objectives of this review were to identify the prevalence of dementia in the prison setting and how prison, health and social care providers assess, diagnose, treat, support and care for prisoners with dementia. A systematic search of the literature from the following databases was undertaken: CINHAL, PubMed, BNI, PsychINFO, and MEDLINE. Search strategies were tailored for each database and included recognised Medical Subject Headings. Hand searching of prominent journals in correctional services and dementia, as well as reference lists of included papers was completed. Open Grey website was searched to identify relevant government, local council and charity publications regarding dementia in the prison setting. The appropriate Critical Appraisal Skills Programmes Checklist for all included studies was completed. Following the application of inclusion and exclusion criteria 10 studies were included in the review. Due to the nature of the data extracted a meta-synthesis was not possible, therefore a thematic synthesis was completed. Three themes emerged: prevalence of dementia in the prison population, identification of older prisoner's needs, and knowledge of correctional officers and legal professionals. The prevalence and incidence of dementia in prison populations remains largely unknown. There is a need for national policies and local strategies that support a multi-disciplinary approach to early detection, screening and diagnosis of cognitive impairment and dementia across prison settings. Alongside the development of structured prison environments, non-pharmacological 
interventions, continued assessment of prisoners with a dynamic care plan, and training for health, social and prison staff and prisoners.

\section{Introduction}

The world's population is aging, which impacts on many aspects of society, one of which is custodial services. Older prisoners are the fastest growing group in the prison population, in England and Wales the number of prisoners aged $50-59$ increased by $100 \%$ and those over 60 by $120 \%$ from 2003 to 2013 , and this trend is predicted to continue (House of Commons Justice Committee, 2013). In the United States of America (USA) the population of older prisoners, defined as those over the age of 55 increased by 79\% from 2000 to 2009 (Beck and Harrison, 2001; West, Sabol and Greenmans, 2010). Similar increases have been observed in Australia as prisoners over the age of 50 rose from $8.3 \%$ to $11.2 \%$ of the prison population from 2000 to 2010 , and in 2017 prisoners over the age of 50 accounted for $12.9 \%$ of prison population (Australian Bureau of Statistics [ABS], 2000; ABS, 2010; ABS, 2017).

Many factors have contributed to the increase of older prisoners, in the UK, Australia and USA the implementation of custodial sentences to discourage crime has resulted in longer sentences with no fixed release dates (Baidawi, Turner, Trother, Browning, Collier, O'Connor et al. 2011; Moll, 2013). In the UK custodial sentences for breaches of bail have been enforced (Ministry of Justice, 2010). Furthermore, convictions for sexual offences are more prevalent in older prisoners and advances in forensic evidence have enabled historic offences to be brought to trial (Yorston, 2015; Resettlement and Care for Older Ex-Offenders and Prisoners [RECOOP], 2015). Mandatory minimum sentencing and reduced options for early release are also cited as reasons for an ageing prison population (Baidawi et al. 2011).

The increase of older prisoners has a significant impact on custodial, health and social care services (Williams, Stern, Mellow, Safer and Greifinger, 2012b). Custodial routines have been developed to support the rehabilitation of younger offenders, and therefore may not support older prisoners with 
increased physical and mental health needs (Angus, 2015). Prisoners are also acknowledged to have an accelerated aging process, which has been defined by Grant (1999) as a 10 year differential, that is a prisoner's physiological health is 10 years advanced of their chronological age. In the UK the prevalence of chronic illness in prisoners aged $50-54$ has been estimated to be $71 \%$ and those 70 and over 92\% (Hayes, Burns, Turnbull and Shaw, 2012). Elements that contribute to prisoners accelerated aging include poor health and life style choices, which commence prior to and during a prison sentence (Maschi, Kwak, Ko and Morrissey, 2012; Williams et al. 2012b).

The definition of an 'older prisoner' has yet to receive consensus, with a current range of $45-65$ years. However, many reports, policies, and governing bodies recognise the definition of an older prisoner as any offender over the age of 50 (Prison Reform Trust, 2010; Public Health England, 2017; Angus, 2015). In addition Indigenous people from Australia and USA have been recognised and classified as older prisoners at a younger age (Baidawi et al. 2011). Therefore, a definition of an older prisoner is essential as the accelerated aging of prisoners impacts on their likelihood to develop chronic illnesses and/or disabilities often before the age of 50 (Williams, Goodwin, Baillargeon, Ahalt, and Walter, 2012a).

A syndrome related to aging, but not a natural part of aging, is that of dementia. The risk of dementia doubles every five years from the age of 65 in the general population (Corrada, Brookmeyer, Paganini-Hill, Berlau and Kawas, 2010). The risk of dementia within the prisoner population may be higher due to accelerated aging and the risk factors associated with this, and further risk factors such as: low educational attainment, higher rates of psychiatric morbidities and traumatic brain injuries (Maschi et al. 2012; Williams et al. 2012b).

Aging prisoners may have an increased risk of developing dementia, yet there remains a lack of information on the prevalence of dementia in prison settings. In the USA the prevalence of dementia has been estimated at a prison level, and ranges from $1 \%$ to $44 \%$, with the highest percentage in a prison specifically for older prisoners (Maschi et al. 2012). There is limited information available for 
Australia or the UK (Patterson, Newman and Doona, 2016). Information is available on the physical and mental health diagnoses of older prisoners, with comparisons to younger prisoners and to the general public, but without including or specifically identifying dementia (Loeb and AbudDagga, 2006; Binswanger, Krueger and Steiner, 2009; Davoren, Fitzpatrick, Caddow, Caddow, O'Neill and Kennedy, 2015). A recent review of the prevalence of psychiatric disorders among older prisoners reported the prevalence of dementia as $3.3 \%$ and cognitive impairment as $11.8 \%$ (Di Lorito, Vollm and Dening, 2018). However, this may not be a true representative as only seven of the nine studies specifically included the diagnosis of dementia.

The need to understand the prevalence of dementia in the prison population is essential to enable the support of the prisoner with dementia, prison staff and the prison service. The onset of cognitive impairment or dementia may leave a prisoner vulnerable. The importance of identifying vulnerable prisoners is to prevent victimization from fellow prisoners and unwarranted disciplinary actions (Williams et al. 2012b; Feckzo, 2014). For prisoners with dementia disciplinary actions may occur as a consequence of their behaviour that is beyond their control, and/or being unable to adhere to the prison routine.

The impact of dementia in the prison population remains largely unexplained and unexplored. Health and social care provision have focused on mental and physical health of prisoners. For example correctional staff have received training to enable them to support prisoners with a serious mental illness (Dvoskin and Spiers, 2004), and primary care teams have been implemented to support prisoners physical health (Wong, Wright, Santomauro, How, Leary and Harris 2018). However neither of these initiatives have a specific focus or agenda with regards to dementia (Steadman, Osher, Robbins, Case and Samuels, 2009; Trestman, Ford, Zhang and Wiesbrock, 2007; Fazel, Hope, O'Donnell and Jacoby, 2004). Further understanding of the impact of dementia within the custodial setting is required to support prisoners with dementia, health and social care staff, as well as prison staff and the prison regime (Wilson and Barboza, 2010). 
The aim of this systematic literature review is to identify: the prevalence of dementia in the prison setting, and how prison, health and social care providers assess; diagnose; treat; support and care for prisoners with dementia.

\section{Methods}

Search Strategy

The following electronic databases were searched from inception to December 2017: CINHAL, PubMed, BNI, PsychINFO, and EMBASE. Search strategies were tailored for each database and included recognised Medical Subject Headings (MeSH), refer to Table 1.

The review process included: hand search of a number of prominent journals in correctional services and dementia; search of the Open Grey website to identify grey literature such as: government local council and charity initiatives within dementia and the prison setting. Finally, screening of reference lists of identified papers was completed.

\section{INSERT TABLE 1 HERE}

Inclusion and Exclusion Criteria

Inclusion criteria were: studies presenting primary data related to prisoners with cognitive impairment or dementia in the prison or custodial setting, published in peer reviewed journals from inception to $31^{\text {st }}$ December 2017 in the English Language. Studies with a focus on older prisoners and/or psychiatric morbidities that provided specific information regarding prisoners with cognitive impairment or dementia were also included.

Exclusion criteria were: studies reporting psychiatric morbidities without specifically identifying dementia, opinion and discursive papers, and grey literature describing programmes implemented in custodial services to support prisoners with dementia with an absence of primary outcome data. Studies exploring cognitive disabilities rather than cognitive impairment were excluded as related to other conditions such as autism, Downs Syndrome or traumatic brain injury. 
Study Selection

The screening process was completed independently by two reviewers JB and AG. All duplicates were removed prior to the commencement of this process. Discussion and agreement of inclusion and exclusion criteria occurred prior to the screening of titles and abstracts to appease disagreements. In the event of a disagreement that could not be negotiated the third author was consulted.

\section{Quality Assessment}

A number of quality assessment tools were applied to appraise included studies due to their different methodological approaches. These included: Joanna Briggs Institute Critical Appraisal Checklist for case control studies (Moola, Munn, Tufanaru, Aromataris, Sears, Sfetcu et al. 2017), Critical Appraisal Skills Programme (CASP) checklist for cohort studies (CASP, 2018), CASP checklist for qualitative studies (CASP, 2018), a critical cross-sectional appraisal tool (Downes, Brennan, Williams and Dena, 2016), and a mixed methods appraisal tool (Pluye, Robert, Cargo, Bartlett, O'Cathain, Griffiths et al. 2011). Only minor elements were identified, the checklists are provided within the additional online information.

\section{Data Extraction}

Data extraction was completed by JB and checked by AG, and included publication, aim, setting, methods, participants, results and an overview of the discussion.

\section{Data Synthesis}

Data from all included studies were extracted to identify key issues and themes though synthesising and interpreting the results. Due to the nature of the data extracted and the different paradigms, designs and methods of each study, a meta-analysis was not possible. Therefore, a thematic synthesis was completed as described by Thomas and Harden (2008). The three stage approach of meta-synthesis was adhered to, which included coding of the text, the development of descriptive 
themes which reflected the primary data, and an interpretative phase of the development of analytical themes. The process was completed by JB and discussed and developed with AG and DJ.

\section{Findings}

Study selection

The inclusion and exclusion criteria were applied to screen and identify relevant papers, the results are summarised in a Preferred Reporting Items for Systematic Reviews and Meta-analysis (PRISMA) diagram (Moher, Liberati, Tetzlaff and Altman, 2009). A number of papers were excluded following; screening of titles ( $n=1518)$, reading of abstracts $(n=251)$, and finally full papers were obtained $(n=68)$, of which 10 met the inclusion and exclusion criteria (refer to Diagram 1 ). One paper was published online in 2017, and then within an issue of the journal in 2018 (Combalbert, Pennequin, Ferrand, Armand, Anselme and Geffray, 2018) and is therefore included within this review.

INSERT DIAGRAM 1 HERE

Study Characteristics

An overview of the characteristics of the included studies are provided in Table 2, studies were completed in; USA ( $n=3)$, UK ( $n=3)$, Australia $(n=2)$, France $(n=1)$, and Sweden $(n=1)$. Studies explored different aspects of dementia in the prison setting, which included: prevalence of older prisoners with cognitive impairment or dementia $(n=2)$, psychiatric diagnosis $(n=1)$, correctional officers knowledge $(n=1)$, identification of the needs of prisoners with cognitive impairment or dementia $(n=4)$, legal professionals knowledge $(n=1)$, and comparison of physical and mental health of older male prisoners to community dwelling men $(n=1)$.

INSERT TABLE 2 HERE

Study Designs 
Study designs varied due to the exploration of different aspects of dementia in the prison setting, which included: cross-sectional semi-structured interviews with validated questionnaires (Fazel, Hope, O’Donnell and Jacoby, 2001; Kingston, Mesurier, Yorston, Wardle and Heath, 2011; Shepherd, Ogloff, Shea, Pfeifer and Paradies, 2017; Combalbert et al. 2018), case note evaluations (Fazel and Grann, 2002; Hayes et al. 2012), case note evaluations and validated questionnaires (Williams, Lindquist, Hill, Baillargeon, Mellow, Greifinger et al. 2009), and round table and Delphi design (Williams et al. 2012a; Patterson et al. 2016). One study applied mixed methods including validated questionnaires and qualitative interviews (Soones, Ahalt, Garrigues, Faigman and Williams, 2014). Validated questionnaires

Studies applied validated questionnaires to address the aim of their research, these included: Geriatric Mental State examination (Fazel et al. 2001; Kingston et al. 2011); Structured Clinical Interview for DSMIV Axis II personality disorders (Fazel et al. 2001; Hayes et al. 2012); Mini- Mental State Examination (Kingston et al. 2011; Hayes et al. 2012; Combalbert et al. 2018); Camberwell Assessment of Need-Forensic Short Version (Hayes et al. 2012; Shepherd et al. 2017). Further validated questionnaires included: Geriatric Attitudes Scale (Soones et al. 2014); Kimberely Indigenous Cognitive Assessment Tool (Shepherd et al. 2017) and Combalbert et al. (2018) included the: Frontal Assessment Battery; Nottingham Health Profile; World Health Organisation Quality of Life Questionnaire and the Scale of Subjective State of Mental Health. The diversity of questionnaires implemented across studies included in this review identifies the current diverse approach to exploring the impact of dementia in the prison population.

Participants

The number of participants within studies ranged from: prisoners $121-262,(n=1,056)$ of whom the majority were male, nurses and healthcare professionals $18-36,(n=83)$, correctional officers $(n=71)$, legal representatives and advocates $(n=72)$, and a comparison with community dwelling males $(n=138)$. 
Operationalisation of age

The operationalisation of older prisoners varied across studies, ranging from prisoners over the age of 50 (Kingston et al. 2011; Hayes et al. 2012; Combalbert et al. 2018) and over the age of 60 (Fazel et al. 2001; Fazel and Grann, 2002). One study exploring prison healthcare professionals understanding of the needs of older prisoners discussed how to define the older prisoner, with the agreement of 55 years or older. However, healthcare professionals also acknowledged services should be inclusive for all with cognitive or functional impairments, regardless of age (Williams et al. 2012a). This was supported by one study which did not refer to age but a diagnosis of dementia or cognitive impairment (Shepherd et al. 2017).

Themes

Three themes emerged from the analysis: 1) Prevalence of dementia in prison populations; 2 ) Identification of older prisoners' needs; 3) Knowledge of correctional officers and legal professionals.

Prevalence of dementia in prison populations

The prevalence of dementia in prison populations ranged from 0.8-18.8\% (Fazel et al. 2001; Shepherd et al. 2017; Kingston et al. 2011; Combalbert et al. 2018), refer to Diagram 2. The difference in identified prevalence of dementia between studies may be due to the different prison populations. Kingston et al. (2011), Fazel et al. (2001) and Combalbert et al. (2018) included the population of four and 15 prisons in England and Wales, and prisons across France respectively. Shepherd et al. (2017) included adult Aboriginal and/or Torres Strait Inslander males and females in regional and metropolitan prisons in Australia, with a mean age of 34.4.

\section{INSERT DIAGRAM 2 HERE}

A further explanation of the difference in the prevalence of dementia across prisons may be the screening and diagnostic tools implemented. Earlier studies of Fazel et al. (2001) and Fazel and 
Grann (2002) applied standardised instruments for identifying psychiatric and personality disorders including the Geriatric Mental State [GMS] (Copeland, Dewey, Henderson, Kay, Neal, Harrison et al. 1988) and the DSM-IV. Whereas, more recent studies applied a specific screening tools to identify cognitive impairment (Kingston et al. 2011; Combalbert et al. 2018), which was the Mini Mental State Examination [MMSE] (Folstein, Folstein and McHugh, 1975). Shepherd et al. (2017) also applied a more culturally appropriate screening tool for the Aboriginal people, the Kimberley Indigenous Cognitive Assessment Tool [KICA] (LoGiudice, Smith, Thomas, Lautenschlager, Almeida, Atkinson et al. 2006).

Kingston et al. (2011) found a disparity between those diagnosed with dementia (2\%) and those with suggested cognitive impairment following cognitive screening with the MMSE (12.8\%). This is comparable with the findings of Combalbert et al. (2018), which following cognitive screening with the MMSE found $18.8 \%$ of prisoners had scores suggestive of dementia. However, the differences between these two studies may be the interpretation of the MMSE results. Combalbert et al. (2018) identified cognitive impairment suggestive of dementia in prisoners scoring less than 23 on the MMSE, whilst Kingston et al. (2011) divided prisoners into those scoring 10-19 (0.8\%) and 20-26 (12\%). Combalbert et al. (2018) was the only study to apply the Frontal Assessment Battery [FAB] (Dubois, Slachevsky, Lituan and Pillon, 2000), and compare older prisoners with older community dwelling men. The $F A B$ is a quick evaluation of executive functioning, with a score of 16 or less suggesting a pathological impairment. Combalbert et al. (2018) found $89 \%$ of prisoners scored 16 or less on the $\mathrm{FAB}$, compared to $50 \%$ of community dwelling men.

The more recent studies have highlighted the need to apply specific cognitive screening tools to accurately identify the prevalence and incidence of cognitive impairment and dementia in prisons. The prevalence of dementia in the prison setting may range from 12.8 to $18.8 \%$, which is higher than community settings (Kingston et al. 2011; Combalbert et al. 2018).

Identification of older prisoner's needs 
The consideration of older prisoners' needs and how to improve the quality of care for prisoners with dementia was explored by experts in prison healthcare (Williams et al. 2012a; Patterson et al. 2016). Older prisoner's needs and unmet needs were also identified through interviews and case note reviews, as well as the application of validated cognitive and forensic need assessments (Hayes et al. 2012; Shepherd et al. 2017).

Experts in prison healthcare identified the need for a list of functional requirements to support older prisoners to maintain independent living, and a framework to support staff to care for and manage older prisoners and those with dementia (Williams et al. 2012a, Patterson et al. 2017). Both studies identified specific needs with regard to prisoners with dementia which included: the development of appropriate accommodation, a multi-disciplinary team approach, alongside specialist care and environments. However experts also recognised the need to acknowledge the financial restraints of prison services (Williams et al. 2012a; Patterson et al. 2017).

Health professionals expressed the need to identify prisoners with cognitive impairment and the importance of developing cognitive screening tools as current tools were considered unsuitable, and were unlikely to identify new prisoners with dementia. Healthcare professionals also recognised the need for cognitive screening to be embedded in a framework to support referral processes in a transparent and consistent manner which was currently lacking (Patterson et al. 2016).

The needs of older prisoners and Aboriginal prisoners have been explored through the application of the Camberwell Assessment of Needs Forensic Short Version [CANFOR-S] (Thomas, Harty, Parrott, McCrone, Slade and Thornicroft, 2003) (Hayes et al. 2012; Shepherd et al. 2017). Older prisoners needs were explored in 5 year age bands from $50-70+$, and Aboriginal prisoners with and without cognitive impairment to identify total need, met need or unmet need. There was no overall significant difference in the total need of older prisoners, but there was a decreased need in daytime activities for prisoners aged 65-69, and an increased need in psychological support for prisoners aged 50-54 (Hayes et al. 2012). Aboriginal prisoners with cognitive impairment had an increased 
unmet need of culturally appropriate daytime activities, an increased experience of racism and difficulties around non-Aboriginal people (Shepherd et al. 2017). Both studies found reduced access to telephones for older prisoners and those with cognitive impairment (Hayes et al. 2012; Shepherd et al. 2017).

Studies identified the need to develop strategies within a cohesive framework to enable the identification, assessment and support of older prisoners and those with cognitive impairment (Williams et al. 2012a; Patterson et al. 2016). Essential elements of a cohesive framework would include the development of an appropriate cognitive screening tool, a multi-disciplinary approach and services specifically for older prisoners and those with dementia. However, this needs to occur alongside an equitable approach to support older prisoners and those with dementia to access generic services for all prisoners.

Knowledge of correctional officers and legal professionals

Correctional officer's identification of prisoners with disabilities was correlated with information recorded within California Department of Corrections Rehabilitation (CDCR) case notes (Williams et al. 2009). There was no significant difference between the number of prisoners diagnosed with dementia who were known $(n=2)$ and unknown $(n=3)$ to their assigned officer. Prisoners identified by officers to have disabilities tended to be older, hospitalised in the last two years, and have a hearing impairment. Disparities occurred in both directions, as CDCR identified specific cases of offenders with dementia unknown by assigned officers, and assigned officers reported higher rates of disability than acknowledged in CDCR reports.

Legal professional's expertise and aging-related training was explored through a questionnaire and in-depth interviews (Soones et al. 2014). Only $29 \%$ of the legal professionals had completed any aging-related training, $67 \%$ stated the need and importance of receiving some or more training, whilst $46 \%$ held the view 'as people grow older, they become less organised and more confused'. Legal professionals' also identified a lack of knowledge on how to identify and respond to cognitive 
impairment, safety risks and referral processes, especially when a surrogate decision-maker was required, and how to optimise services for older offenders and those with cognitive impairment (Soones et al. 2014).

Studies identified the need for robust training programs to improve correctional officers and legal professional's knowledge of the aging process, cognitive impairment and disabilities related to aging. The development of a comprehensive standardized checklist was also recommended to support the identification of cognitive impairment, disabilities and issues relating to offenders safety and declining health (Williams et al. 2009; Soones et al. 2014).

\section{Discussion}

Three broad themes were identified in this review and represent the current initiatives and focus to understand the impact of dementia in the prison setting, which include the prevalence of dementia, identification of older prisoner's needs and knowledge of correctional officers and legal professionals.

The prevalence of cognitive impairment and dementia in prison populations remains unclear, due to the likelihood of underreporting and a prison regime, which may prevent identification of cognitive impairment or the early stages of dementia (Sterns, Lax, Sed, Keohane and Sterns, 2008). However, more recently studies have explored cognitive impairment through the use of validated cognitive screening tools. However, the applicability and validity of these tools for prison populations is questionable.

The MMSE was frequently applied in the studies in this review. However, the first five questions on the MMSE assess orientation to time, and many prisoners without cognitive impairment become disorientated in the prison setting due to environmental factors (Grassian, 2008). The reliability and validity of the MMSE for prisoners has not been explored and data remains lacking to support the use of this tool with prisoners (Williams et al. 2012b). This review highlights issues of sensitivity and 
specificity of the use of the MMSE within the prison setting, as Hayes et al. (2012) found no difference in MMSE scores amongst prisoners aged 50 to over 70, which seems an unlikely finding.

The need for an optimum cognitive screening tool was identified by health care professionals; as was the need to screen all prisoners on admission, and annually for older prisoner's (Williams et al. 2012b). A screening tool to access prison activities of daily living (PADLs) has been developed and includes five actions: dropping to the floor for alarms, standing for head counts, ambulating to the dinner hall for meals, hearing orders from staff, and climbing up and down from the top bunk (Williams et al. 2009). However, this instrument is based on an American prison setting and has not been further validated or tested for sensitivity or specificity with regards to identifying cognitive impairment.

The need for an optimum screening tool remains as healthcare professional's find current tools unsuitable and unlikely to identify new cases of dementia in prisoners (Williams et al. 2012a; Patterson et al. 2016). The consensus among healthcare professionals was a simple memory test, such as remembering three words and a cognition test, such as drawing a clock face. If a prisoner failed either or both of these tests, further cognitive screening would be undertaken (Patterson et al. 2016).

The identification of the needs of older prisoners has been a priority in England and Wales within two reports released by the HM Chief Inspectors of Prisons (2004; 2013). Older prisoners were perceived by staff as: 'old and quiet', more compliant than younger prisoners and posed no threat to the prison regime, which led to a lack of assessment and identification of older prisoner's needs. Recommendations from the HM Chief Inspectors included identification of older prisoner's healthcare, social care and prison needs, alongside the development of a national strategy for older prisoners by Her Majesty's Prison and Probation Service (HMPPS). The need remains for national strategies and local frameworks, which clearly define the responsibilities of all services involved in a 
transparent process of assessment, identification, and implementation of care and support for older prisoners.

In the UK the Prison and Probation Ombudsman report (2017) identified the need for a specific focus on dementia and complex needs, as identified $4 \%$ of the deaths investigated included a prisoner with a diagnosis of dementia. Recommendations included the need for a multidisciplinary approach to support the physical and mental health of prisoners with dementia with skilled staff to complete risk assessments, a coordinated approach to care and the sharing of information.

In England and Wales Prison service there remains no national strategy regarding dementia (House of Commons, 2017). In the USA strategies to support prisoners with cognitive impairment and dementia have begun to be developed and include early, diagnosis, structured environment, training of staff, and non-pharmacological interventions (Wilson and Barboza, 2010).

The development of frameworks to support policy and prison reforms to address the needs of prisoners with cognitive impairment and dementia needs to include the training of prison staff and legal professionals. In the USA, Alzheimer's Association has designed and implemented dementia awareness training specifically for prison officers. Whereas in the UK Alzheimer's Society has implemented dementia awareness training for both prison officers and prisoners (Moll, 2013). However, the extent of such training initiatives and the impact has yet to be robustly evaluated.

Training initiatives for prisoners have included how to provide social care, this approach enables prisoners to support aging fellow prisoners with complex needs (Stewart, 2018). Training initiatives for prisoners include: listeners, who are prisoners trained by the Samaritans to support fellow prisoners experiencing distress; insiders, who are prisoners who support new prisoners and provide practice advice, information and reassurance; and hospice volunteers, who are prisoners trained to provide practical support, social and companionship to those who are terminally ill (South, Bagnall and Woodall, 2017). Training initiatives for prisoners have been found to support the peer caregivers, those receiving their care and the prison regime (Wilson and Leob, 2016). Currently, 
these initiatives have not included training or specific information on how to support a prisoner with dementia.

A number of initiatives to support prisoners with dementia have begun to be implemented. The Special Needs Program for Inmates with Dementia in California Men's Colony state prison, which includes the training of prison officers and nursing staff, alongside prisoners to support prisoners with dementia (Hodel and Sanchez, 2012). The Buddy Model is another initiative that has been implemented across prisons in South West England by Devon County Council (2014). Prisoners are recruited and trained in assisting other prisoners with social care needs and non-intimate personal care. An element of the buddy training involves cognitive impairment and dementia. However, both of these initiatives have yet to have robust evaluations completed or published.

The limitations of this review need to be acknowledged. We included research conducted in English, and so insights and information reported in languages other than English are not captured in this review. A large amount of grey literature was identified that has not been comprehensively reported in this review.

\section{Conclusion}

The aging prison population presents challenges to the prison services, as well as health and social care personnel. Growing numbers of older prisoners increases the likelihood of cognitive impairment, dementia and dementia-related conditions. There is an urgent need to develop and implement programs for screening, regular assessment and health preserving activities for people with dementia in the prison environment. This will only be effective if prison, health and social care staff are equipped with the skills necessary to recognise cognitive impairment and work collaborative within the multi-disciplinary team.. 
Funding

This research received no specific grant from any funding agency in the public, commercial, or notfor-profit sectors.

Declaration of conflicting interests

The Authors declare that there is not conflict of interest. 
References

Angus, C. (2015). Older prisoners, trends and challenges. New South Wales Parliament e-brief

14/2015. (Retrieved from). https://www.parliament.nsw.gov.au/researchpapers/Documents/olderprisoners-trends-and-challenges/Older\%20prisoners\%20-\%20trends\%20and\%20challenges.pdf

Australian Bureau of Statistics. (2010). Prisoners in Australia 2010. cat. no. 4517.0. Canberra: ABS.

Australian Bureau of Statistics. (2000). Prisoners in Australia 2000. cat. no. 4517.0. Canberra: ABS.

Baidawi, S., Turner, S., Trotter, C., Browning, C., Collier, P., ... Sheehan, R. (2011). Older prisoners-A challenge for Australian corrections. Trends \& Issues in Crime and Criminal Justice, Australian Government Department of Criminology 426.

Beck, A.J., Harrison, P.M. (2001). Prisoners in 2000. Washington, DC: US Department of Justice, Office of Justice Programs. NCJ 188207.

Binswanger, I.A., Krueger, P.M., Steiner, J.F. (2009). Prevalence of chronic medical conditions among jail and prison inmates in the United States compared with the general population. Journal of Epidemiology and Community Health 63 (11), 912-9.

Critical Appraisal Skills Programme. (2018). CASP (Qualitative) Checklist. (Retrieved from). https://casp-uk.net/wp-content/uploads/2018/01/CASP-Qualitative-Checklist.pdf

Critical Appraisal Skills Programme. (2018). CASP (Cohort) Checklist. (Retrieved from). https://caspuk.net/wp-content/uploads/2018/01/CASP-Cohort-Study-Checklist.pdf

Combalbert, N., Pennequin, V., Ferrand, C., Armand, M., Anselme, M., Geffray, B. (2018). Cognitive impairment, self-perceived health and quality of life of older prisoners. Criminal Behaviour and Mental Health 28 (1), 36-49. 
Copeland, J.R., Dewey, M.E., Henderson, A.S., Kay, D.W., Neal, C.D., ... Shiwach, R. (1988). The Geriatric Mental State (GMS) used in the community: replication strokes of the computerized diagnosis AGECAT. Psychological Medicine 18 (1), 219-23.

Corrada, M., Brookmeyer, R., Paganini-Hill, A., Berlau, D., Kawas, C. (2010). Dementia incidence continues to increase with age in the oldest old: the 90+ study. Annals of Neurology 67 (1), 114-121.

Cox, J.F., Lawrence, J.E. (2010). Planning services for elderly inmates with mental illness. Corrections Today June, 52-57.

Davoren, M., Fitzpatrick, M., Caddow, F., Caddow, M., O'Neill, C., ... Kennedy, H.G. (2015). Older men and older women remand prisoners: mental illness, physical illness, offending patterns and needs. International Psychogeriatrics 27 (5), 747-755.

Devon County Council. (2014). Implementation of Social Care in Prisons under the Care Act (2014). (Retrieved from). https://www.local.gov.uk/sites/default/files/documents/implementation-social$\underline{\text { car-da3.pdf }}$

Di Lorito, C., Vollm, B., Dening, T. (2018). Psychiatric disorders among older prisoners: a systematic review and comparison study against older people in the community. Aging and Mental Health 22 (1), 1-10.

Downes, M.J., Brennan, M.L., Williams, H.C., Dena, R.S. (2016). Development of a critical appraisal tool to assess the quality of cross-sectional studies (AXIS). BMJ Open 6 e011458.

Dubois, B., Slachevsky, A., Litvan, I., Pillon, B. (2000). The FAB: a frontal assessment battery at bedside. Neurology 55, 1621-1626.

Dvoskin, J.A., Spiers, E.M. (2004). On the role of correctional officers in prison mental health. Psychiatric Quarterly 75 (1), 41-59. 
Fazel, S., Grann, M. (2002). Older criminals: a descriptive study of psychiatrically examined offenders in Sweden. International Journal of Geriatric Psychiatry 17, 907-913.

Fazel, S., Hope, T., O’Donnell, I., Jacoby, R. (2001). Hidden psychiatric morbidity in elderly prisoners. British Journal of Psychiatry 179, 535-539.

Fazel, S., Hope, T., O’Donnell, I., Jacoby, R. (2004). Unmet treatment needs of older prisoners: a primary care survey. Age and Ageing 33, 396-398.

Fecko, A. (2014). Dementia in the incarcerated elderly adult: Innovative solutions to promote quality care. Journal of the American Association of Nurse Practitioners 26, 640-648.

Folstein, M., Folstein, S., McHugh, P. (1975). "Mini-mental state”: a practical method for grading the cognitive state of patients for the clinician. Journal of Psychiatric Research 12, 189-198.

Grassin, S. (2008). Neuropsychiatric effects of soliatary confinement. In A.E. Ojeda (Ed.) The trauma of psychological torture (pp 113-126). Westport Praeger/Greenwood Publishing Group.

Grant, A. (1999) . Elderly inmates: Issues for Australia. Trends \& Issues in Crime and Criminal Justice no. 115. Canberra: Australian Institute of Criminology.

Hayes, A.J., Burns, A., Turnbull, P., Shaw, J. (2012). The health and social needs of older male prisoners. International Journal of Geriatric Psychiatry 27, 1155-1162.

HM Chief Inspector of Prisons. (2004). No problems - old and quiet. Older prisoners in England and Wales. London, Stationery Office.

HM Chief Inspector of Prisons. (2013). Justice Committee Inquiry into Older Prisoners. London, Stationery Office.

Hodel, B., Sanchez, H.G. (2012). The Special Needs Program for Inmate-Patients with Dementia (SNPID): A psychosocial program provided in the prison system. Dementia 12 (5), 54-660. 
House of Commons. (2017). Mental Health in prisons. Eigth Report of Session 2017-19. (Retrieved from). https://publications.parliament.uk/pa/cm201719/cmselect/cmpubacc/400/400.pdf

House of Commons Justice Committee. (2013). Older Prisoners. Firth Report of Session 2013-4. Volume 1: Report, together with formal minutes, oral and written evidence. House of Commons, London: The Stationary Office Limited.

Kingston, P., Le Mesurier, N., Yorston, G., Wardle, S., Heath, L. (2011). Psychiatric morbidity in older prisoners: unrecognised and undertreated. International Psychogeriatrics 23 (8), 1354-1360.

Loeb, S., AbuDagga, A. (2006). Health-related research on older inmates: An integrative review. Research in Nursing and Health 29, 556-565.

LoGiudice, D., Smith, K., Thomas, J., Lautenschlager, N.T., Almeida, O.P., ... Flicker, L. (2006). Kimberley Indigenous Cognitive Assessment Tool (KICA): development of a cognitive assessment tool for older indigenous Australians. International Psychogeriatrics 18, 269-80.

Maschi, T., Kwak, J., Ko, E., Morrissey, M. (2012). Forget me not: Dementia in prison. The Gerontologist 52 (4), 441-451.

Ministry of Justice. (2010). Offender Management Caseload Statistics 2009. Ministry of Justice Statistics Bulletin, London, Stationary Office.

Moher, D., Liberati, A., Tetzlaff, J., Altman, D.G., The PRISMA Group. (2009). Preferred reporting items for systematic reviews and meta-analyses: The PRISMA statement. PLoS Medicine 6 (6), e1000097.

Moll, A. (2013). Losing tract of time. Dementia and the ageing prison population: treatment challenges and examples of good practice. Mental Health Foundation. (Retrieved from). https://www.mentalhealth.org.uk/sites/default/files/losing-track-of-time-2013.pdf 
Moola, S., Munn, Z., Tufanaru, C., Aromataris, E., Sears, K., ... Mu, P-F. (2017). Chapter 7: Systematic reviews of etiology and risk . In: Aromataris E, Munn Z (Editors). Joanna Briggs Institute Reviewer's Manual. The Joanna Briggs Institute. (Retrieved from). https://reviewersmanual.joannabriggs.org/ Patterson, K., Newman, C., Doona, K. (2016). Improving the care of older persons in Australian prisons using the Policy Delphi method. Dementia 15 (5), 1219-1233.

Pluye, P., Robert, E., Cargo, M., Bartlett, G., O'Cathain, A., ... Rousseau, M.C. (2011). Proposal: A mixed methods appraisal tool for systematic mixed studies reviews. (Retrieved from). http://mixedmethodsappraisaltoolpublic.pbworks.com

Prison and Probation Ombudsman. (2017). Independent investigations. Annual Report 2016-17. (Retrieved from).

https://assets.publishing.service.gov.uk/government/uploads/system/uploads/attachment data/file 628974/ppo-annual-report-2016-17.PDF

Prison Reform Trust. (2010). Doing Time: Good practice with older people in prison - the views of prison staff. (Retrieved from).

http://www.prisonreformtrust.org.uk/uploads/documents/doingtimegoodpractice.pdf

Public Health England. (2017). Health and social care needs assessments of the older prison population. A guidance document. (Retrieved from).

https://www.gov.uk/government/uploads/system/uploads/attachment data/file/662677/Health a nd social care needs assessments of the older prison population.pdf

Resettlement and Care for Older ex-Offenders and Prisoners (RECOOP). (2015). (Retrieved from). http://www.recoop.org.uk/pages/resources/

Shepherd, S.M., Ogloff, J.R.P., Shea, D., Pfeifer, J.E., Paradies, Y. (2017). Shepherd Aboriginal prisoners and cognitive impairment: the impact of dual disadvantage on Social and Emotional Wellbeing. Journal of Intellectual Disability Research 61 (4), 385-397. 
Soones, T., Ahalt, C., Garrigues, S., Faigman, D., Williams, B.A. (2014). "My Older Clients Fall Through Every Crack in the System": Geriatrics Knowledge of Legal Professionals. Journal of American Geriatrics Society 62, 734-739.

South, J., Bagnall, A.M., Woodall, J. (2017). Developing a typology for peer education and support delivered by prisoners. Journal of Correctional Health Care 23 (2), 214-229.

Steadman, H.J., Osher, F.C., Robbins, P.C., Case, B., Samuels, S. (2009). Prevalence of serious mental illness among jail inmates. Psychiatric Sciences 60 (6), 761-765.

Stern, A.A., Lax, G., Sed, C., Keohane, P., Sterns, R.S. (2008). The growing wave of older prisoners: A National survey of older prisoner health, mental health and programming. Corrections Today August, 70-76.

Stewart, W. (2018). What does the implementation of peer care training in a UK prison reveal about prisoner engagement in peer caregiving? Journal of Forensic Nursing 14 (1), 18-26.

Thomas, J., Harden, A., (2008). Methods for thematic synthesis of qualitative research in systematic reviews. BMC Medical Research Methodology 8: 44.

Thomas, S., Harty, M.A., Parrott, J., McCrone, P., Slade, M., Thornicroft, G. (2003). CANFOR:

Camberwell Assessment of Need - Forensic Version. Cambridge University Press: London

Trestman, R.L., Ford, J., Zhang, W., Wiesbrock, V. (2007). Current and lifetime psychiatric illness among inmates not identified as acutely mentally ill at intake in Connecticut's jails. The Journal of the American Academy of Psychiatry and the Law 35, 490-500.

West, H.C., Sabol, W.J., Greenmans, S.J. (2010). Prisoners in 2009. Washington, DC: US Department of Justice Programs. NCJ 231675.

Wion, R., Loeb, S. (2016). End-of-life behind bars. A systematic literature review. American Journal of Nursing 116 (3), 24-36. 
Yortson, G.A. (2015). Managing aggression and violence in older people. London: The Royal College of Psychiatrists.

Wiliams, B.A., Lindquist, K., Hill, T., Baillargeon, J., Mellow, J., ... Walter, L.C. (2009). Caregiving Behind Bars: Correctional Officer Reports of Disability in Geriatric Prisoners. Journal of American Geriatric Society 57, 1286-1292.

Williams, B.A., Goodwin, M.D., Baillargeon, J., Ahalt, C., Walter, L.C. (2012a). Addressing the Aging Crisis in U.S. Criminal Justice Healthcare. Journal of American Geriatric Society 60 (6), 1150-1156.

Williams, B.A., Stern, M.F., Mellow, J., Safer, M., Greifinger, R.B. (2012b). Aging in correctional custody: Setting a policy agenda for older prison health care. Framing Health Matters 102 (8), 14751481.

Wilson, J., Barboza, S. (2010). The looming challenge of dementia in prisons. Correct Care 24 (2), 1013. 
Table 1: Search terms, data bases and number of hits

\begin{tabular}{|l|c|c|c|c|c|}
\hline Search strategy & CINAHL & PsychINFO & PubMed & BNI & MEDLINE \\
\hline $\begin{array}{l}\text { Offenders 'or' criminals 'or' } \\
\text { prisoner 'or' inmate 'and' dementia } \\
\text { 'or' alzheimers 'or' vascular } \\
\text { dementia 'or' lewy body 'or' } \\
\text { frontotemporal 'or' cognitive } \\
\text { impairment 'or' memory loss 'or' } \\
\begin{array}{l}\text { cognitive decline 'or' mild cognitive } \\
\text { impairment }\end{array}\end{array}$ & 67 & 344 & 170 & 343 & 227 \\
\hline $\begin{array}{l}\text { Custodial 'or' prisons 'or' forensic } \\
\text { 'or' custodial health 'and' dementia } \\
\text { 'or' alzheimers 'or' vascular } \\
\text { dementia 'or' lewy body 'or' } \\
\text { frontotemporal 'or' cognitive } \\
\text { impairment 'or' memory loss 'or' } \\
\text { cognitive decline 'or' mild cognitive } \\
\text { impairment }\end{array}$ & 27 & 132 & 63 & 643 & 432 \\
\hline
\end{tabular}

Total hits: 2,448 


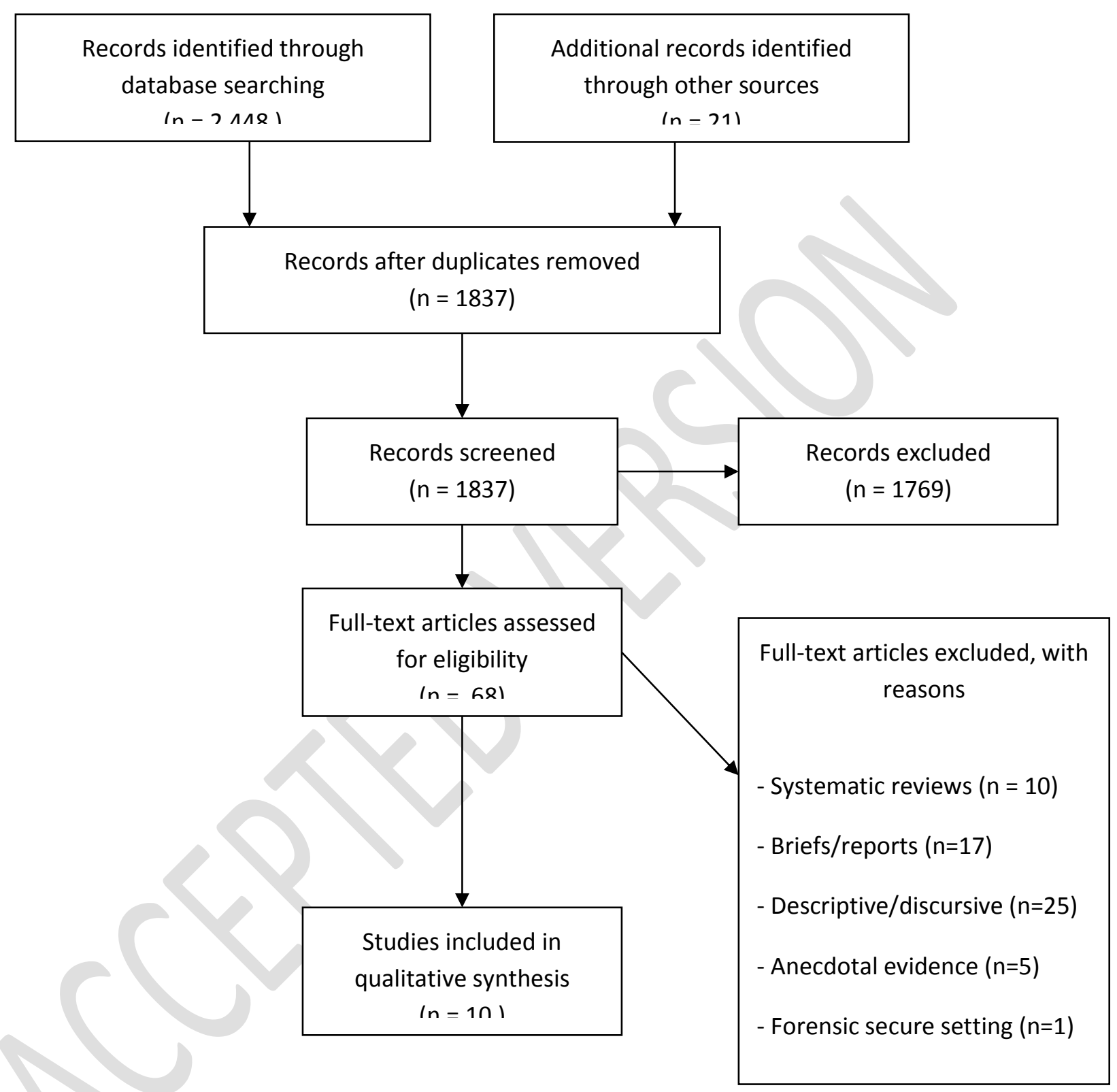

Adapted from Moher et al. (2009). 
Table 2: Overview of included studies

\begin{tabular}{|c|c|c|c|c|}
\hline $\begin{array}{l}\text { Author } \\
\text { Year } \\
\text { Country }\end{array}$ & $\begin{array}{l}\text { Aim } \\
\text { Setting }\end{array}$ & $\begin{array}{l}\text { Methods } \\
\text { Participants }\end{array}$ & Results & Discussion \\
\hline $\begin{array}{l}\text { Fazel et al., } \\
2001\end{array}$ & $\begin{array}{l}\text { To determine } \\
\text { the prevalence } \\
\text { of psychiatric } \\
\text { morbidity in } \\
\text { elderly } \\
\text { sentenced } \\
\text { prisoners } \\
\text { Prisons in } \\
\text { England and } \\
\text { Wales }(n=15)\end{array}$ & $\begin{array}{l}\text { Semi-structured interviews: } \\
\text {-Geriatric Mental State } \\
\text { Examination (GMS exam) } \\
\text {-The Structured Clinical Interview } \\
\text { for DMS-IV Axis II personality } \\
\text { disorders (SCID-II) } \\
\text { Correlation with: } \\
\text {-Medical records and reception } \\
\text { health screen data were accessed } \\
\text { Prisoners } \\
\text {-Over the age of } 60 \text { ( } n=203 \text { ) } \\
\text {-Mean age } 65.6 \text { (SD 4.8) }\end{array}$ & $\begin{array}{l}\text { GMS Exam supported by Automated } \\
\text { Geriatric Examination for Computer } \\
\text { Assisted Taxonomy (GMS-AGECAT): } \\
\text {-Psychiatric illness ( } n=64,31.5 \%) \\
\text {-Neuroses ( } n=52,25.6 \%) \\
\text {-Major depressive episode ( } n=15,7.4 \% \text { ) } \\
\text {-Psychosis ( } n=10,4.9 \%) \\
\text {-Substance misuse ( } n=10,4.9 \%) \\
\text {-Dementia ( } n=2,1 \%) \\
\text { SCID-II: } \\
\text { - Personality disorder ( } n=61,30 \%)\end{array}$ & $\begin{array}{l}\text { The authors suggested those } \\
\text { diagnosed with dementia were } \\
\text { successfully diverted prior to } \\
\text { sentencing and that people with } \\
\text { dementia do not have the capacity } \\
\text { to commit serious crimes for which } \\
\text { imprisonment in the consequence. }\end{array}$ \\
\hline $\begin{array}{l}\text { Fazel and } \\
\text { Grann, } \\
2002\end{array}$ & $\begin{array}{l}\text { Exploration of } \\
\text { psychiatric } \\
\text { diagnoses of } \\
\text { younger and } \\
\text { older prisoners } \\
\text { referred by }\end{array}$ & $\begin{array}{l}\text { Evaluation of structured court- } \\
\text { ordered forensic psychiatric } \\
\text { evaluations } \\
\text { Offenders who completed a }\end{array}$ & $\begin{array}{l}\text { Psychiatric diagnoses in prisoners over } \\
\text { the age of } 60 \text { : } \\
\text {-Psychotic illness ( } n=67,32 \%) \\
\text {-Personality disorder }(n=41,20 \%)\end{array}$ & $\begin{array}{l}\text { Older compared to younger } \\
\text { offenders referred for psychiatric } \\
\text { assessment were more likely to be } \\
\text { diagnosed with dementia or an } \\
\text { affective psychosis and less likely } \\
\text { to be diagnosed with a personality }\end{array}$ \\
\hline
\end{tabular}




\begin{tabular}{|c|c|c|c|c|}
\hline Sweden & $\begin{array}{l}\text { courts for } \\
\text { psychiatric } \\
\text { assessment } \\
\text { Swedish courts }\end{array}$ & $\begin{array}{l}\text { forensic psychiatric evaluation } \\
\text { between } 1988-2000 \\
\text { Offenders ( } n=7297) \\
\text {-Under the age of } 60(n=7297) \\
\text {-Over the age of } 60(n=210)\end{array}$ & $\begin{array}{l}\text {-Substance abuse }(n=31,15 \%) \\
\text {-Depressive/anxiety disorder ( } n=16,8 \%) \\
\text {-Dementia ( } n=15,7 \%) \\
\text { Prisoners over the age of } 60 \text { deemed } \\
\text { legally insane: } \\
\text {-Other psychoses ( }=42,43 \%) \\
\text {-Dementia ( } n=12,12 \%) \\
\text {-Schizophrenia ( } n=12,12 \%) \\
\text {-Personality disorder ( } n=7,7 \%) \\
\text {-Substance abuse ( } n=6,6 \%) \\
\text {-Depressive/anxiety disorders ( } n=4,4 \%)\end{array}$ & $\begin{array}{l}\text { disorder or schizophrenia. } \\
\text { Dementia was virtually non- } \\
\text { existent in offenders under the age } \\
\text { of } 60 \text {, but was a factor that } \\
\text { significantly increased the } \\
\text { likelihood of legal insanity by eight } \\
\text { times among older prisoners. }\end{array}$ \\
\hline $\begin{array}{l}\text { Williams et } \\
\text { al., } 2009\end{array}$ & $\begin{array}{l}\text { To assess } \\
\text { correctional } \\
\text { officers' } \\
\text { knowledge of } \\
\text { health and } \\
\text { disability of } \\
\text { their assigned } \\
\text { prisoners } \\
\text { compared with } \\
\text { prison reports }\end{array}$ & $\begin{array}{l}\text { Cross-sectional study } \\
\text { Correctional officer questionnaires } \\
\text {-Identify assigned geriatric } \\
\text { prisoners disability status and } \\
\text { healthcare needs }\end{array}$ & $\begin{array}{l}\text { Unknown prisoners: } \\
\text {-To assigned officer ( } n=211,34.1 \%) \\
\text {-Over the age of } 70(n=20,27 \%) \\
\text {-CDCR identified a } 76 \text { year old women } \\
\text { with dementia unknown to prison officers } \\
\text {-Prison officers identified an } 80 \text { year old } \\
\text { man with cognitive impairment unknown } \\
\text { to CDCR }\end{array}$ & $\begin{array}{l}\text { Recognition of geriatric disability in } \\
\text { prison needs improvement and } \\
\text { need to include training of } \\
\text { correction officers in how to } \\
\text { identify older prisoners with } \\
\text { disability, as well as formal and } \\
\text { informal communication between }\end{array}$ \\
\hline
\end{tabular}




\begin{tabular}{|c|c|c|c|c|}
\hline & $\begin{array}{l}\text { California } \\
\text { Department of } \\
\text { Corrections and } \\
\text { Rehabilitation }\end{array}$ & $\begin{array}{l}\text { Correctional officers ( } n=71) \\
\text { assigned to geriatric prisoners } \\
\text { ( } n=618 \text { ) from CDCR prisons }(n=11)\end{array}$ & $\begin{array}{l}\text { Known prisoners more likely to be: } \\
\text {-Slightly older ( } p=0.05) \\
\text {-Hospitalised in last } 2 \text { years }(p<0.01) \\
\text {-Have a hearing impairment }(p=0.04)\end{array}$ & $\begin{array}{l}\text { prison officers and reported } \\
\text { information. }\end{array}$ \\
\hline $\begin{array}{l}\text { Kingston et } \\
\text { al } \\
2011 \\
\text { United } \\
\text { Kingdom }\end{array}$ & $\begin{array}{l}\text { To determine } \\
\text { the prevalence } \\
\text { of psychiatric } \\
\text { disorders, } \\
\text { including } \\
\text { dementia, in } \\
\text { prisoners } 50 \\
\text { years and over } \\
\text { Four prisons: } \\
\text { HMP: } \\
\text {-Dovegate } \\
\text {-Featherstone } \\
\text {-Shrewsbury } \\
\text {-Stafford }\end{array}$ & $\begin{array}{l}\text { Assessment of prison records and } \\
\text { interviews using: } \\
\text {-Geriatric Mental State } \\
\text { Examination (GMS Exam) } \\
\text {-Mini-Mental State Examination } \\
\text {-Short Form } 12 \\
\text { Prisoners approached ( } n=237 \text { ) } \\
\text { Prisoners who agreed to } \\
\text { participate ( } n=121) \\
\text { Age of participants } \\
-50-59 \text { ( } n=74) \\
-60-69 \text { ( } n=40)\end{array}$ & $\begin{array}{l}\text { GMS Exam supported by Automated } \\
\text { Geriatric Examination for Computer } \\
\text { Assisted Taxonomy (GMS-AGECAT): } \\
\text {-Mental disorder ( } n=60,50 \%) \\
\text {-Depressive disorder ( } n=50,83 \%) \\
\text {-Dementia ( } n=2 \text { ) } \\
\text { MMSE: } \\
\text {-Score in the } 10-19 \text { range ( } n=1,0.8 \%) \\
\text { (demonstrating possible dementia) } \\
\text {-Score in the } 20-26 \text { range ( } n=15,12 \%) \\
\text { (demonstrating signs of cognitive } \\
\text { impairment) } \\
\text { Short Form } 12 \\
\text {-Mental Health Scores (mean 47.5) } \\
\text {-Physical Health Scores (mean 45.9) }\end{array}$ & $\begin{array}{l}\text { Mental disorders in older prisoners } \\
\text { are common, but despite recent } \\
\text { training initiatives they often go } \\
\text { undetected. } \\
\text { Prisoners themselves accurately } \\
\text { self-reported mental disorders, but } \\
\text { the best way of detecting dementia } \\
\text { in this population remains unclear. }\end{array}$ \\
\hline
\end{tabular}




\begin{tabular}{|c|c|c|c|c|}
\hline & & $-70+(n=7)$ & & \\
\hline $\begin{array}{l}\text { Williams et } \\
\text { al } \\
2012 a\end{array}$ & $\begin{array}{l}\text { To identify and } \\
\text { propose a set of } \\
\text { priorities to } \\
\text { support the care } \\
\text { of older } \\
\text { prisoners } \\
\text { USA } \\
\text { correctional } \\
\text { health experts }\end{array}$ & $\begin{array}{l}\text { Round table meeting of } 29 \text { national } \\
\text { experts in correctional health } \\
\text { National experts } \\
\text {-Chief medical officers ( } n=9) \\
\text {-Psychologists/psychiatrists ( } n=7) \\
\text {-Academic physicians ( } n=5) \\
\text {-Prisoner advocates }(n=2) \\
\text {-Foundation officers }(n=2) \\
\text {-Nurse }(n=1) \\
\text {-Lawyer }(n=3)\end{array}$ & $\begin{array}{l}\text { Consensus recommendations: } \\
\text {-Define older prisoner } \\
\text {-Train staff and health care providers } \\
\text {-Define functional impairment } \\
\text {-Screen for dementia } \\
\text {-Identify needs of older women prisoners } \\
\text {-Create policies for geriatric housing units } \\
\text {-Identify release and re-entry challenges } \\
\text {-Improve medical releases policies } \\
\text {-Enhance prison palliative care programs }\end{array}$ & $\begin{array}{l}\text { Importance of national and state } \\
\text { policy makers to work with } \\
\text { corrections and community } \\
\text { organizations to understand the } \\
\text { needs of older prisoners and the } \\
\text { development of policies to support } \\
\text { continuum of care within current } \\
\text { services and budgets. }\end{array}$ \\
\hline $\begin{array}{l}\text { Hayes et al } \\
2012\end{array}$ & $\begin{array}{l}\text { To investigate } \\
\text { the health } \\
\text { needs of older } \\
\text { prisoners, to } \\
\text { compare needs } \\
\text { within age } \\
\text { groups and to } \\
\text { identify a useful } \\
\text { age cut-off for } \\
\text { service planning }\end{array}$ & $\begin{array}{l}\text { Cross-sectional study } \\
\text { Interview case note review: } \\
\text {-Burvill Grid for physical health } \\
\text {-Structured Clinical Interview for } \\
\text { Diagnostic and Statistical Manual } \\
\text { of Mental Disorders IV (SCID-I) and } \\
\text { personality disorders (SCID-II) } \\
\text {-Mini-Mental State Examination }\end{array}$ & $\begin{array}{l}\text { Physical health } \\
-90 \% \text { of prisoners had a diagnosed long } \\
\text { term health condition } \\
\text {-Most common conditions were } \\
\text { osteoarthritis and hypertension }\end{array}$ & $\begin{array}{l}\text { Older prisoners physical and } \\
\text { mental health needs are } \\
\text { dominated by chronic conditions, } \\
\text { unlike the majority of the prison } \\
\text { population, who have acute } \\
\text { disorders such as substance misuse } \\
\text { and psychosis. }\end{array}$ \\
\hline
\end{tabular}




\begin{tabular}{|c|c|c|c|c|}
\hline & $\begin{array}{l}\text { North West } \\
\text { Prison Service } \\
\text { Area in the UK }\end{array}$ & $\begin{array}{l}\text { (MMSE) } \\
\text {-Camberwell Assessment of Need } \\
\text { Forensic Short Version (CANFOR-S) } \\
\text { Male participants ( } n=262) \text { : } \\
\text {-aged } 60 \text { years and over }(n=165) \\
\text {-aged } 50 \text { to } 59 \text { years }(n=97)\end{array}$ & $\begin{array}{l}\text { disorder }(p<0.01) \\
\text { Needs } \\
\text {-No significant differences needs } \\
\text {-Significant differences across age groups } \\
\text { on } 4 \text { domains: daytime activities, food, } \\
\text { support for psychological support, money } \\
\text { and telephone access }\end{array}$ & $\begin{array}{l}\text { The age of fifty appears to be a } \\
\text { useful age to define 'older } \\
\text { prisoners' and service provision } \\
\text { should reflect this is in a national } \\
\text { management strategy. }\end{array}$ \\
\hline $\begin{array}{l}\text { Soones et al } \\
2014\end{array}$ & $\begin{array}{l}\text { To assess the } \\
\text { ability of legal } \\
\text { professionals to } \\
\text { respond to age- } \\
\text { related } \\
\text { conditions that } \\
\text { could affect } \\
\text { legal outcomes }\end{array}$ & $\begin{array}{l}\text { Mixed methods } \\
\text { Quantitative survey } \\
\text {-Geriatric Attitudes Scale } \\
\text {-knowledge of aging and aging- } \\
\text { related health } \\
\text {-professional training } \\
\text {-Public defenders and legal } \\
\text { advocates ( } n=42 \text { ) } \\
\text {-Lawyers }(n=18) \\
\text {-Judges }(n=4)\end{array}$ & $\begin{array}{l}\text { Geriatrics Attitude Scale } \\
\text {-Positive attitudes towards older people } \\
\text { ( } n=72,100 \% \text { ) } \\
\text {-Older people are: 'less organised and } \\
\text { more confused' (46\%) } \\
\text { Knowledge of aging/aging-related health } \\
\text {-Knowledgeable ( } n=10,14 \%) \\
\text {-Lack of knowledge on how depression, } \\
\text { dementia and delirium ( } n=39,54 \% \text { ) } \\
\text {-Received training ( } n=20,29 \%) \\
\text {-Importance of training ( } n=46,67 \% \text { ) } \\
\text { Lack of knowledge and understanding of: }\end{array}$ & $\begin{array}{l}\text { These recommendations should } \\
\text { support and reduce criminal justice } \\
\text { and health care costs associated } \\
\text { with older adults whose criminal } \\
\text { behaviour is due to underlying } \\
\text { cognitive impairment, as would } \\
\text { support interventions for older } \\
\text { prisoners, which may include } \\
\text { alternatives to incarceration. }\end{array}$ \\
\hline
\end{tabular}




\begin{tabular}{|c|c|c|c|c|}
\hline & & $\begin{array}{l}\text { Qualitative interviews } \\
\text {-Attorneys }(n=5) \\
\text {-Judges }(n=2) \\
\text {-Social workers }(n=3)\end{array}$ & $\begin{array}{l}\text { - Aging and aging-related health } \\
\text {-How to identify/respond to dementia } \\
\text {-Safety risks and referral processes } \\
\text {-Optimising services upon release }\end{array}$ & \\
\hline $\begin{array}{l}\text { Patterson et } \\
\text { al., } \\
2016\end{array}$ & $\begin{array}{l}\text { To develop tools } \\
\text { and procedures } \\
\text { related to } \\
\text { managing the } \\
\text { care of, } \\
\text { including the } \\
\text { identification } \\
\text { and assessment, } \\
\text { of older persons } \\
\text { with dementia } \\
\text { who are } \\
\text { imprisoned } \\
\text { New South } \\
\text { Wales, Australia }\end{array}$ & $\begin{array}{l}\text { Modified approach of the Policy } \\
\text { Delphi method, using both surveys } \\
\text { and facilitated discussion groups } \\
\text { Round } 1 \text { (online survey) } \\
\text {-Registered Nurses ( } n=36 \text { ) } \\
\text { Rounds } 2 \text {-4 (discussion group) } \\
\text {-Registered nurses ( } n=5) \\
\text {-Nursing unit manager ( } n=2) \\
\text {-Nurse practitioner ( } n=2) \\
\text {-Clinical nurse consultant }(n=2) \\
\text {-Clinical nurse educator }(n=2) \\
\text {-Health service manager }(n=2) \\
\text {-Geriatrician ( } n=1 \text { ) }\end{array}$ & $\begin{array}{l}\text { Round } 1 \\
\text {-Cognitive screening tools were } \\
\text { sometimes unsuitable ( } n=12,42.9 \% \text { ) or } \\
\text { very unsuitable ( } n=6,21.4 \% \text { ) } \\
\text { Round } 2 \\
\text {-The process for identifying older } \\
\text { prisoners with dementia was agreed } \\
\text { - Modifications needed to the current } \\
\text { cognitive tool } \\
\text { Round } 3 \\
\text {-Global Deterioration Scale with minor } \\
\text { modification was agreed as an } \\
\text { appropriate cognitive screening tool }\end{array}$ & $\begin{array}{l}\text { The outcome of the Policy Delphi } \\
\text { method was a process for assessing } \\
\text { older people with dementia in } \\
\text { prison and an illustration of how } \\
\text { the care of older people with } \\
\text { dementia in prison can be } \\
\text { managed. } \\
\text { Recommendations included the } \\
\text { training of staff in dementia care at } \\
\text { both rural and remote correctional } \\
\text { centres, the development of } \\
\text { discharge planning/post release } \\
\text { services and the need for } \\
\text { collaborative working with } \\
\text { community health and social care } \\
\text { providers. }\end{array}$ \\
\hline
\end{tabular}




\begin{tabular}{|c|c|c|c|c|}
\hline & & -Occupational therapist $(n=2)$ & $\begin{array}{l}\text {-Care of older persons with dementia } \\
\text { through care planning by a locally based } \\
\text { multidisciplinary team }\end{array}$ & \\
\hline $\begin{array}{l}\text { Shepherd et } \\
\text { al., } \\
2017 \\
\text { Australia }\end{array}$ & $\begin{array}{l}\text { To identify } \\
\text { Social and } \\
\text { Emotional } \\
\text { Wellbeing and } \\
\text { unmet needs } \\
\text { among } \\
\text { cognitively and } \\
\text { non-cognitively } \\
\text { impaired } \\
\text { Aboriginal } \\
\text { people in } \\
\text { custody } \\
\text { Victorian } \\
\text { regional and } \\
\text { metropolitan } \\
\text { prisons, } \\
\text { Australia }\end{array}$ & $\begin{array}{l}\text { Semi-structured interviews } \\
\text {-Social and Emotional Wellbeing } \\
\text { (SEWB) survey } \\
\text {-Kimberley Indigenous Cognitive } \\
\text { Assessment (KICA) } \\
\text {-Camberwell Assessment of Need- } \\
\text { Forensic Short Version (CANFOR } \\
\text { SV) } \\
\text { Aboriginal and/or Torres Strait } \\
\text { Islander ( } n=122 \text { ) } \\
\text { Age: mean } 34.4 \text { (SD=10.3) } \\
\text { Sex: male ( } n=107 \text { ), female ( } n=15 \text { ) }\end{array}$ & $\begin{array}{l}\text { Cognitive impairment (KICA) } \\
\text {-Only one participant received a low } \\
\text { score suggesting a potential dementia } \\
\text { SEWB } \\
\text { Participants with cognitive impairment } \\
\text { were more likely to have: } \\
\text {-An illness/disability in the past } 12 \\
\text { months ( } p<0.01 \text { ) } \\
\text {-Family member in prison ( } p<0.008 \text { ) } \\
\text {-Treated badly because of their } \\
\text { indigenous heritage ( } p<0.06 \text { ) } \\
\text { CANFOR SV } \\
\text {-Participants with cognitive impairment } \\
\text { activities and access to a telephone }\end{array}$ & $\begin{array}{l}\text { Prisoners with cognitive } \\
\text { impairment demonstrated poorer } \\
\text { coping mechanisms, experienced } \\
\text { more racism, and felt } \\
\text { uncomfortable around non- } \\
\text { Aboriginal people. The implication } \\
\text { was a reduced access to culturally } \\
\text { meaningful activities in custody. } \\
\text { There is a need for culturally } \\
\text { appropriate cognitive screening, } \\
\text { on-going support and access in } \\
\text { custody and on release, through } \\
\text { collaboration and information } \\
\text { sharing between health, } \\
\text { correctional, employment, } \\
\text { educational and disability services. }\end{array}$ \\
\hline $\begin{array}{l}\text { Combalbert } \\
\text { et al }\end{array}$ & $\begin{array}{l}\text { To explore } \\
\text { cognitive }\end{array}$ & $\begin{array}{l}\text { Semi-structured interview } \\
\text {-Mini-Mental State Examination }\end{array}$ & $\begin{array}{l}\text { Significantly different scores on the } \\
\text { MMSE and FAB for prisoners compared }\end{array}$ & $\begin{array}{l}\text { The MMSE and FAB demonstrated } \\
\text { that cognitive impairment is more }\end{array}$ \\
\hline
\end{tabular}




\begin{tabular}{|c|c|c|c|c|}
\hline France & $\begin{array}{l}\text { performance of } \\
\text { older men in } \\
\text { prison to } \\
\text { community } \\
\text { dwelling men, } \\
\text { and the impact } \\
\text { of cognitive } \\
\text { decline on } \\
\text { perceived } \\
\text { health and } \\
\text { quality of life } \\
\\
\text { Different types } \\
\text { of penal } \\
\text { institutions in } \\
\text { France }\end{array}$ & $\begin{array}{l}\text { (MMSE) } \\
\text {-Frontal Assessment Battery (FAB) } \\
\text {-Nottingham Health Profile (NHP) } \\
\text {-Scale of subjective state of mental } \\
\text { health } \\
\text {-World Health Organisation Quality } \\
\text { of Life Questionnaire (WHO QoL) } \\
\text { Prisoners ( } n=138) \\
\text { Comparison men }(n=138)\end{array}$ & $\begin{array}{l}\text { to comparison men ( } p<0.0001 \text { ) } \\
\text { FAB } \\
\text {-Prisoners ( } n=106,89 \% \text { ) scored equal to } \\
\text { or less than } 16 \text { (impairment) compared to } \\
\text { comparison men ( } n=53,50 \% \text { ) } \\
\text { MMSE } \\
\text {-Prisoners ( } n=26,18.8 \% \text { ) scored } 23 \text { or less } \\
\text { (impairment) compared to comparison } \\
\text { men ( } n=1,0.72 \% \text { ) } \\
\text { Significant differences between physical } \\
\text { and mental health and quality of life, } \\
\text { prisoners reported more negative } \\
\text { responses on each item and scale than } \\
\text { comparison men }\end{array}$ & $\begin{array}{l}\text { pronounced in older men in prison } \\
\text { than in older men living in the } \\
\text { community. } \\
\text { Prisoners with low scores on the } \\
\text { MMSE may struggle to adapt to a } \\
\text { prison regime and building } \\
\text { relationships with staff and fellow } \\
\text { inmates. }\end{array}$ \\
\hline
\end{tabular}


Diagram 2: Prevalence of dementia in prison populations

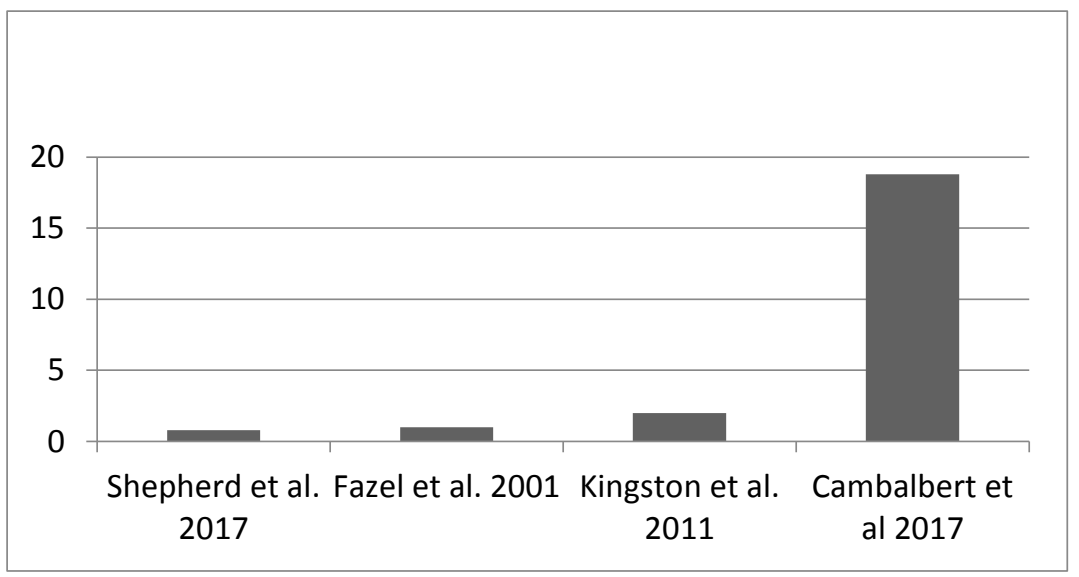

